УДК 614.612.16

П. М. Полушкін, Д. В. Гальченко, М. В. Наговська

Дніпропетровський національний університет ім. Олеся Гончара

\title{
АСПЕКТИ ПУЛЬСОВОЇ ДІАГНОСТИКИ, ПИТАННЯ ПІДГОТОВКИ ДО КОМП'ЮТЕРНОЇ ОБРОБКИ СФІГМОГРАМ ЛЮДИНИ
}

\begin{abstract}
Вивчено сучасні варіанти досліджень пульсу, виконано аналіз раціональності використання окремих методик пульсової діагностики, виявлено особливості трактування критеріїв пульсової діагностики, їх наукове обгрунтування. Здійснено спробу підготовки до комп'ютерної обробки матеріалів пульсової діагностики - сфігмографії людини. Застосовано оцінку ефективності попередніх діагностичних результатів за матеріалами математичної обробки сфігмограм. Здійснено спробу прогнозування достовірності результатів можливих варіантів математичної обробки для комп'ютерного використання.
\end{abstract}

П. Н. Полушкин, Д. В. Гальченко, М. В. Наговская

Днепропетровский национальный университет им. Олеся Гончара

\section{АСПЕКТЫ ПУЛЬСОВОЙ ДИАГНОСТИКИ, ВОПРОСЫ ПОДГОТОВКИ К КОМПЬЮТЕРНОЙ ОБРАБОТКЕ СФИГМОГРАММ ЧЕЛОВЕКА}

\begin{abstract}
Изучены современные варианты исследований пульса, проведен анализ рациональности использования отдельных методик пульсовой диагностики, выявлены особенности трактовки критериев пульсовой диагностики, их научное обоснование. Осуществлена попытка подготовки к компьютерной обработке материалов пульсовой диагностики - сфигмографии человека. Проведена оценка эффективности предварительных результатов по материалам математической обработки сфигмограмм. Осуществлена попытка прогнозирования достоверности результатов возможных вариантов математической обработки для компьютерного использования.
\end{abstract}

\author{
P. N. Polushkin, D. V. Galchenko, M. V. Nagovska \\ Oles' Honchar Dnipropetrovsk National University
}

\section{ASPECTS OF PULSE DIAGNOSTICS, PROBLEMS OF PREPARATION OF HUMAN SPHYGMOGRAMS FOR COMPUTER PROCESSING}

Modern methods of the pulse diagnostics were studied, the rationality of using different methods for pulse diagnostics was evaluated and the features of criteria interpretation of the pulse diagnostics methods and its scientific validation were revealed. The attempt of preparation of the pulse diagnostics data (human sphygmograms) for the further computer processing was made. The efficiency of preliminary results was assessed by the mathematical treatment of the sphygmograms. The attempt of prognostication of the reliability of possible variants of the mathematical treatment for the computer processing was made.

\section{Вступ}

Одним із важливих методів дослідження з метою діагностики та спостереження за станом хворого у процесі лікування, реанімації, інтенсивної терапії є пульсова діаг- 
ностика. Вона істотно доповнюе загальну діагностику та дозволяє виконувати моніторинг хворих. Пульс - ритмічне коливання артеріальної стінки, що викликається змінами тиску крові при кожній систолі. Пульсова діагностика богатогранна, тому що містить цілу низку окремих методик: загальноприйнята та східна методики, апаратна методика - сфігмографія.

Загальноприйняте визначення стану здоров'я за пульсом базується на дослідженні пульсу на двох руках, за допомогою трьох пальців (вказівного, середнього, безіменного) з урахуванням 7 основних характеристик.

1. Відсутність пульсу передбачає агонію, смерть, хворобу Такаясі, хворобу Рейно, облітеруючий ендартериїт.

2. Частота пульсу за хвилину у дорослого у стані спокою - 50-80 ударів за хвилину, пульс менше 50 - брадисистолія, понад 90-100 - тахісистолія.

3. Ритм у нормі - розмірений, при патології - аритмічний (екстрасистолія, пароксизмальна тахікардія, миготлива аритмія, серцеві блокади).

4. Напруження пульсу визначає пружність стінки артерії; виділяють слабку, задовільну, добру, дуже добру напруженість пульсу.

5. Наповнення пульсу визначає наявність кровонаповнення артерії; виділяють погане, задовільне, добре, залишкове наповнення пульсу.

6. Форми пульсу поділяють на:

- нормальну форму пульсової хвилі;

- високу форму, яка передбачає недостатність клапанів аорти, гарячку, гіпертиреоз, гіпертонічні кризи, відкритий баталів протік;

- малий пульс передбачає зомління, колапс, шок, замерзання, вади зі стенозами: аортального, трикуспідального, мітрального, легеневого відділів серця, анемії, хронічні порушення кровообігу;

- парадоксальний пульс передбачає пухлини легенів, цироз легенів, перикардити.

7. Дефіцит пульсу визначає наявність миготливої аритмії.

Східні методики визначення діагнозу та спостереження за хворими передбачають різні варіанти дослідження. Перший варіант поглибленого вивчення пульсу:

- триступеневе дослідження пульсу проводиться за допомогою трьох пальців обома руками;

- під вказівним пальцем досліджуємо кровозабезпечення відповідної половини голови, руки;

- під середнім пальцем досліджуємо кровозабезпечення відповідної половини живота, нирок, селезінки;

- під підмізиним пальцем досліджуємо кровозабезпечення відповідної половини органів таза, ноги. працівника.

Дослідження за цим варіантом передбачає значний досвід медичного

Другий варіант поглибленого вивчення пульсу. Дослідження проводять у 6 точках зліва та 6 точках справа. Спочатку досліджують поверхневий пульс у 3 точках, зліва визначають характеристики: у 1-й точці досліджують стан тонкої кишки, у 2-й жовчний міхур, у 3-й - сечовий міхур. Справа у 1-й - товста кишка, у 2-й - шлунок, у 3-й - три відділи тулуба. При дослідженні глибокого пульсу зліва в 1-й точці досліджують стан серця, у 2-й - стан печінки, у 3-й - напруженість нирок. Справа у 1-й визначається стан легенів, у 2-й - стан селезінки, у 3-й - функції нирок.

Найперспективнішою, на нашу думку, особливо для комп'ютерного забезпечення, має бути сфігмографія. Прилади, за допомогою яких реєструють пульсову хвилю, 
називають сфігмографи, а запис - сфігмограмою. Останніми роками запис пульсової хвилі здійснюється тензометричними, капацитетними, п'єзоелектричними, фотоелектричними та електромагнітними перетворювачами.

Запис сфігмограми, як правило, проводять у горизонтальному положенні досліджуваного (на спині) з витягнутими уздовж тулуба руками. При встановленні датчика на a. carotis підборіддя відводять у протилежий бік. Датчик установлюють на пульсуючу артерію на рівні верхнього краю щитоподібного хряща. При записі пульсу 3 a. radialis i a.femoralis датчик відповідно встановлюють на пульсову точку a. radialis i на середину lig. inguinale. Запис слід проводити при постійній силі та швидкості руху стрічки $-50 \mathrm{Mm} / \mathrm{c}$.

Сфігмограми, записані з артерій еластичного типу (aorta, a. carotis, a. subclavia), характеризують центральний пульс. Сфігмограми, записані з a. radialis, a. femoralis та інших периферичних артерій м'язового типу, характеризують так званий периферичний пульс. Характер сфігмограми центрального пульсу значною мірою зумовлюється серцевою діяльністю (силою скорочення, ударним об'ємом серця, швидкістю підвищення тиску в серці та судинах). Ці чинники меншою мірою відбиваються на периферичних судинах, так що периферичний пульс більшою мірою відображає функціональний стан судинної стінки.

Наприклад, аортальні пороки дають характерні зміни на сфігмограмі з a. carotis. За ними можна судити як про вид порушення, так і про тяжкість ураження клапанів. При аортальній недостатності відсутня друга хвиля - пресистолічна. Може з'явитися пульс у формі «водяного молотка». Цей вид пульсу з'являється при могутній серцевій систолі та зниженому опорі периферичних судин. Реєструється він також при колаптоїдних станах. При аортальній недостатності частіше спостерігається pulsus celer. Спостерігається він і при базедовій хворобі. Для стенозу аорти характерний pulsus tardus. Він має трикутну форму з подовженням періоду досягнення вершини, 3 малою інцизурою та відсутністю дикротичної хвилі. При важкому аортальному стенозі без недостатності описано анакротичний пульс. Останній характеризується тим, що перша (основна) хвиля та западина між двома основними хвилями записуються на висхідному плечі. При комбінованому аортальному пороку може бути зареєстрований pulsus bis feriens, за якого дві перші основні хвилі каротидної сфігмограми однаково виражені. При мітральних і природжених пороках серця на сфігмограмі не знаходять змін, які можна використовувати для підтвердження діагнозу цих захворювань.

У загальних рисах органічні зміни відбиваються головним чином на анакротичному плечі сфігмограми, а функціональні - частіше на катакротичному плечі та його складових частинах. При функціональних порушеннях після навантаження або зігрівання руки хворого сфігмограми набувають нормального вигляду, а при органічних ураженнях вони не змінюються або стають більш характерними.

Базуючись на сфігмографії як найоб'єктивнішому методі дослідження пульсу, виконали спробу підготовки сфігмограми до комп'ютерної обробки.

\section{Матеріал і методи досліджень}

Об’єкт досліджень - сфігмограми, осцилограми, роздруковані на принтері. Із метою підготовки сфігмограм, осцилограм до комп’ютерної обробки застосовано закон розподілу Раллея та вимірювання площини під пульсовою кривою з використанням рядів Котельникова, Фур'є. Кожна пульсова хвиля має своє уявне математичне очікування та свою дисперсію. Після відповідної математичної обробки площ під пульсовою кривою одержували результат, який порівнювали зі стандартом нормальної 
сфігмограми, стандартами бази даних патологічних станів. Площа під пульсовою кривою вираховувалась смугою від точок дотику кожної пульсової хвилі з ізоелектричною лінією. При дослідженні використано робочу гіпотезу: для кожної окремої патології існує свій результат площі під пульсовою кривою та довжини пульсової лінії. Кожна пульсова хвиля має своє математичне очікування (Q) та дисперсію (D). Для сфігмограми центрального та периферичного пульсу характерний ряд специфічних особливостей. Сфігмограма центрального пульсу у молодих і здорових людей за Luisada та Bramwell складається 3 трьох основних хвиль: 1) ударна хвиля; 2) припливна хвиля; 3) дикротична хвиля.

\section{Результати та їх обговорення}

У здорових людей пресистолічна хвиля сфігмограми із сонної артерії реєструється у 80 \% випадків (рис. 1). Вершина пульсової кривої має округлі контури, а в окремих випадках являє собою плато систоли. Інцизура розташовується у верхній або середній третині катакротичного плеча. Хвиля діастоли добре виражена.

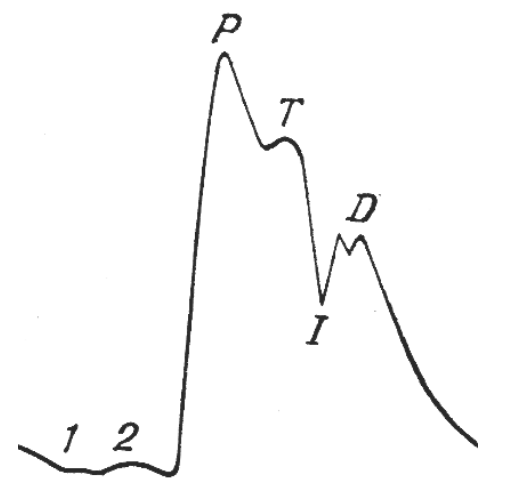

Рис. 1. Нормальна сфігмограма 3 a. carotis: 1,2 - пресистолічні хвилі; $P$ - ударна хвиля; $T$ - припливна хвиля; $I$ - інцизура; $D$ - дикротична хвиля

Крім цих хвиль у пресистолі реєструються дві малі хвилі. Перша, з менш виразним зображенням, зумовлена скороченням передсердя. Друга, ясніша, розташовується безпосередньо перед початком висхідного плеча. Вважають, що вона відображає здуття аортальних клапанів при підвищенні тиску в лівому шлуночку під час ізометричного скорочення шлуночків. Ударна хвиля починається високим плечем (анакрота), причому вершина ії відповідає за часом середині систоли. Далі йде легке спадання, так зване плато. Припливна хвиля утворюється у другій половині систоли, вона заокруглена. За нею йде низхідне (катакротичне) плече. Припускають, що вона відображає підсумовування основної хвилі 3 рефлектованими хвилями 3 периферії. Периферична сфігмограма складається 3 двох великих хвиль: швидковисхідної хвилі систоли і дикротичної. Інцизура менш виражена і заокруглена. Дикротична хвиля також закруглена. Висхідна частина кривої периферичного пульсу залежить від сили серцевої систоли та ударного об'єму, з одного боку, і від опору судин, з іншого. Низхідна частина сфігмограми залежить від функціонального стану судин.

У здорової людини дикротична хвиля 3 a. radialis в 78 \% випадків розташовується в середній третині катакротичного плеча, в $22 \%$ - у нижній третині, у жодному випадку - у верхній третині. Дикротична хвиля 3 a. femoralis в $60 \%$ у дітей записується в нижній третині катакротичного плеча, у $23 \%$ - у средній третині, а в $17 \%$ - не реєструється. 


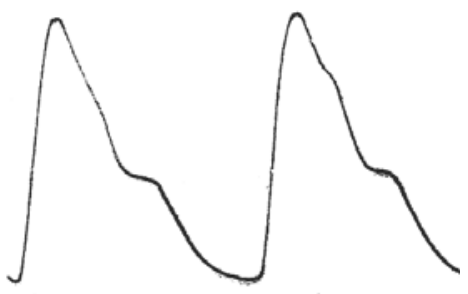

Рис. 2. Нормальна сфігмограма 3 a. radialis (a. femoralis)

Аналіз форми артеріального пульсу дозволяє зробити висновки про роботу серця та стан периферичних судин. При деяких патологічних станах припливна хвиля може бути виражена сильніше першої, утворювати пізній горбок систоли. Розслаблення шлуночка на початку діастоли викликає зворотний рух крові до нього та швидке зниження тиску в аорті, що закінчується закриттям півмісяцевих клапанів. У цей час на сфігмограмі записується інцизура, якою завершується систола та починається діастола. Інцизура центрального пульсу у дорослих гостра, добре виражена, розташована на 2/3 від основи катакротичного плеча. Частина діастоли сфігмограми починається третьою (дикротичною) хвилею. Після закриття аортальних клапанів кров, що повертається в лівий шлуночок, стикається зі стулками клапанів і дає відбиту хвилю до периферії.

Результати математичної обробки пульсової кривої при серцево-судинній патології

Таблиця з використанням рядів Котельникова, Фур'є

\begin{tabular}{|l|c|c|c|c|c|c|c|c|}
\hline \multicolumn{1}{|c|}{ Форма пульсу } & $\begin{array}{c}\text { Довжина } \\
\text { пульсової лінії }\end{array}$ & $D$ & $\begin{array}{c}\text { Висота } \\
\text { пульсової хвилі }\end{array}$ & $D$ & $\begin{array}{c}\text { Довжина } \\
\text { основи }\end{array}$ & $D$ & $\begin{array}{c}\text { Площа, } \\
\text { мм }^{2}\end{array}$ & $D$ \\
\hline Нормальний & 53 & 8 & 23 & 4 & 22 & 7 & 253 & 15 \\
\hline Швидкий & 56 & 5 & 28 & 3 & 9 & 3 & 126 & 6 \\
\hline Півнячий гребінець & 81 & 7 & 27 & 4 & 41 & 5 & 553 & 10 \\
\hline Водяний молоток & 66 & 6 & 20 & 5 & 15 & 6 & 150 & 8 \\
\hline Твердий & 51 & 4 & 20 & 2 & 25 & 4 & 250 & 13 \\
\hline Анакротичний & 75 & 8 & 26 & 3 & 32 & 3 & 416 & 12 \\
\hline Подвійний & 60 & 4 & 19 & 4 & 30 & 6 & 285 & 7 \\
\hline
\end{tabular}

3 урахуванням нормальних (стандартних) сфігмограм і їх співвідношення до показникових особливо патологічних сфігмограм, характерних для серцево-судинної патології, виконано вимірювання довжини пульсової кривої 3 можливими дисперсіями (D), висотою пульсової хвилі, довжиною основи пульсової хвилі, площі пульсової хвилі, можливими їх дисперсіями з використанням рядів Котельникова, Фур'є. Досліджено варіанти нормального пульсу практично здорових людей і хворих із серцевосудинною патологією та специфічними формами пульсу: швидкий, «півнячий гребінь», «водяний молоток», твердий, анакротичний, подвійний (табл.). Отримані результати застосовано для формування математичної терапії та реанімації. За допомогою нашої модифікації використання критерію відповідністі $\chi^{2}$, з урахуванням нульової гіпотези, виконано визначення вірогідності та короткочасного прогнозування змін можливої форми пульсу протягом 24 годин моніторингу.

\section{Висновки}

Пульсова діагностика істотно доповнює загальну діагностику та дозволяє виконувати моніторинг пацієнтів із серцево-судинними захворюваннями протягом 24 годин моніторингу. Виконано спробу використання результатів математичної обробки сфіг- 
мограм при дослідженнях випадків серцево-судинних захворювань для формування математичної основи комп'ютерної програми моніторингу пульсу в умовах інтенсивної терапії та реанімації. Перспективною $є$ розробка якісно нової сфігмографії на основі варіантів поглибленого вивчення поверхневого та глибокого пульсу на $a$. radialis в 6 точках лівої та 6 точках правої руки.

\section{Бібліографічні посилання}

1. Генри Л. Электропунктурная диагностика по Р. Фоллю. - Канада, Ванкувер, 1975. - 101 с.

2. Нетрадиційна діагностика / П. М. Полушкін, Д. В. Гальченко, О. В. Алсібай, Ф. Ф. Клімов. Д. : РВВ ДНУ, 2007. - 80 с.

3. Селченок К. В. Тайны восточной медицины. - Воронеж : Модэк, 1994. - 360 с.

4. Цзинь-Синь Чжуан Китайская народная медицина. - М. : Знание, 1989. - 320 с.

5. Чучалин А. Г. Клиническая диагностика / А. Г. Чучалин, Е. В. Бобков. - М. : Литтера, 2004. $312 \mathrm{c}$.

6. Decaban A. Research of Sphygmograms of Early Childhood // Baltimore. - Brit. Med. J. - 2000. P. 148-159.

7. Natake J. Biological and Clinical Aspects of Sphygmograms / J. Natake, S. Suzuki. - Tokyo, 1997. $403 \mathrm{p}$.

8. Common medical diagnoses / M. Patrice, M. Healey, J. Edwin, M. Jacobson // Lange Basic Science Series. - Brit. Med. J., McGraw - Hill Companies, 2006. - P. 214-256.

Надійшла до редколегії 12.03.2012 